\title{
Assessment of Feeding and Watering Practices for Raising Goats in Punjab, Pakistan
}

\author{
M.S. Muhammad ${ }^{*}$ M.S. Khan ${ }^{1}$ and A. Waheed ${ }^{2}$ \\ Department of Livestock Production \\ University of Veterinary and Animal Sciences
}

Lahore

\begin{abstract}
Household surveys were conducted to assess feeding and watering practices and cost for rearing goats at two sites (Bahawalpur and Faisalabad) in Punjab, Pakistan. Farmers ( $n=300,50$ from each of six villages) were interviewed regarding various types of feeding and watering management and cost incurred on feeding goats. Common feed stuffs and involvement of gender in rearing goats were found similar at both sites. Feeding on waste lands was the main source of feeding. Ponds and rivers were the main watering source at one site while hand pump was the main water source at the other site. Offering water twice a day was the most common practice. Sites differed for various feeding and watering practices. Training of farmers on better utilize of available resources and improvement of pasture lands and other necessities would enhance goat productivity and lead towards efficient utilization of available genetic resources.
\end{abstract}

Keywords: Feeding and watering practices, feeding cost, feeding types, household surveys

\section{INTRODUCTION}

Goats are important in food security concern as well as supplementary income for the rural households. A major segment of the people is inhabitants of rural areas and they keep a large proportion of livestock particularly goats. Goats are usually considered as zero input animals as no special feedings are offered. Common management practices done in rural areas for goat production needed elaboration. Household survey provides a key tool to such exploration. Present study was conducted to investigate the type of feeding stuff, management practices and related cost involved in goat production in rural areas of the Punjab, Pakistan.

\section{MATERIALS AND METHODS}

Household survey was conducted in two districts of the Punjab viz. Bahawalpur (Site-I) and Faisalabad (Site-II) from Jun 2010 to Dec 2012. Site-1 was located south of the Sutlej River and lies in the Cholistan region. The second site (Site-II) was located in Faisalabad district with the river Ravi flowing on the Eastern and the Chenab on the Western boundaries. Three villages were randomly selected from both the sites.

\footnotetext{
1 Department of Animal Breeding and Genetics, University of Agriculture, Faisalabad, Pakistan

Faculty of Veterinary Sciences, Bahauddin Zakariya University Multan, Pakistan

* Corresponding author: maqsoodmuhammad@hotmail.com
} 


\section{Household survey}

There were two type of households; goat owners and non-owners. The household (HH) survey was conducted for only the goat owners. Households were randomly sampled. In each village, from a complete list of households, owners of the goats were identified. The second step was the random selection of the required number $(n=50$ in each village) of owners and of non-owners of goats. Five "additional" households were selected in case a household refuses to participate in the survey. A community leader, or a person of similar category was tasked to inform the selected households in advance of the survey and that their willingness availability for the interview.

The following information was collected as per questioner/ proforma regarding management of goat; feeding stuff/type, feeding cost (PKR), amount fed (Kg), sources for feed purchase, watering practices in different seasons, watering frequency, feeding and water management etc. The data thus collected were analyzed applying Chi square test by using SPSS software (SPSS, 1999).

\section{RESULTS AND DISCUSSION}

Household survey revealed important features about rural livestock and livestock production system. The common livestock species found in these sites were cattle, goat, chicken and donkey.

\section{Feeding practices}

Farmers offered different materials for feeding their goats. Most of the farmers used commercial concentrates at both experimental sites. Majority of farmers grazed their goats at Bahawalpur, but feed ingredients were provided to goats at Faisalabad. The differences for various feed types between two sites were significant $(\mathrm{P}<0.01)$ for almost all of the feed stuffs except for wheat straw, kitchen waste and concentrates (Table 1).

\section{Purchase of feed}

Site-I and II differed significantly $(\mathrm{P}<0.05)$ for cost of feed. The differences between villages were also significant for feeding cost and amount fed. Similarly there was significant $(\mathrm{P}<0.05)$ difference between two sites with regards to amount fed (Table 2). The experimental sites have significant differences for sources of feed $(\mathrm{P}<0.01)$ as shown in Table 3. Most of the farmers at site-II purchased feed from other sources than the main markets (Table 3). It seemed that either approach to main market was difficult or they did not find enough time to go to the market. 
Table 1. Feed type used by farmers at two sites

\begin{tabular}{rccc}
\hline Feed type & Farmers at Site-I & $\begin{array}{c}\text { Farmers at } \\
\text { Site-II }\end{array}$ & $\begin{array}{c}\text { Significance } \\
\text { level }\end{array}$ \\
\hline Rice straw & 11 & 26 & 0.001 \\
Wheat straw & 8 & 9 & 0.643 \\
Kitchen waste & 9 & 9 & 0.901 \\
Commercial concentrates & 32 & 31 & 0.650 \\
Grazing on cropland & 70 & 8 & 0.000 \\
Green fodder & 1 & 18 & 0.000 \\
Feed ingredients & 23 & 37 & 0.001 \\
\hline
\end{tabular}

Table 2. Average feeding cost (PKR) per head for 6 months study period

\begin{tabular}{rcccc}
\hline & \multicolumn{2}{c}{ Feeding cost (PKR) } & \multicolumn{2}{c}{ Amount fed (Kg) } \\
\hline Village & Site-I & Site-II & Site-I & Site-II \\
I & $4504.2 \pm 3757.4^{* *}$ & $1954 \pm 2226.3$ & 1.67 & $1.76^{*}$ \\
II & $823.9 \pm 1502.3^{* *}$ & $4892.9 \pm 6862.2$ & 1.57 & $1.76^{*}$ \\
III & $2080.3 \pm 3394.7$ & $2091.25 \pm 3356$ & $1.67^{\mathrm{NS}}$ & 1.60 \\
Overall & $2439.6 \pm 3099.5^{*}$ & $3260.5 \pm 5153.3$ & 1.64 & $1.71^{*}$ \\
\hline
\end{tabular}

$*=\mathrm{P}<0.05 ; * *=\mathrm{P}<0.01 ; \mathrm{NS}=$ Non-significant $1 \mathrm{PKR}=0.01 \mathrm{USD}$

\section{Feeding and watering management}

The differences for different watering sources in various seasons are shown in Table 4. Ponds were the main watering sources in different villages at Bahawalpur. Number of farmer providing water from river, pond, hand pump and other sources differed significantly between two sites for all seasons. For watering frequency, both sites did not differ significantly only for 'throughout the day' and 'others' watering practices (Table 5). As regards the 'who collects waters' both side differed for number of HH heads (Table 6). Cost of watering (in PKR) was significantly $(\mathrm{P}<0.01)$ higher at Faisalabad $(90.5 \pm 240.6)$ than at Bahawalpur (52.9 \pm 117.4$)$. The differences between sites for 'who waters', who prepares feed' and 'who feeds goats' are given in Table 8, most of them were significant. The feeding stuffs those are normally used for feeding goats were almost similar at both sites. Feeding practices depended upon the availability of pastures, household labour and time. Usually no other labourers were hired for feeding or watering goats. Some keeper offered commercial feeds in order to optimize growth to get maximum profits. Panin (2000) reported that farmers showed interest in keeping small ruminants, support our findings. The reasons would be lesser investment, less expenditure and ease of keeping and potential source of income, and most probably a potential alternative source of agriculture farm income. Ayalew et al. (2003) reported net benefits from goats, revealed the interest of farmers in crossbred goats. Study of Ellis (2003) revealed that poverty was strongly associated with lack of livestock and agricultural land. It means that livestock/goats would provide additional income thus supporting the family. Our results also were in line with that of Finan (2011) who revealed 
the participation of women in goat keeping. It meant that livestock played a major role in poverty reduction and can help eradicate this by facilitating poor farmers through proper marketing facilities of their product and produce.

Table 3. Sources of feed purchase

\begin{tabular}{lccc}
\hline Source of Feed & Site-I & 'Site-II & Significance level \\
\hline Market & 1 & 6 & 0.002 \\
Local shop & 4 & 26 & 0.000 \\
Other places & 5 & 34 & 0.000 \\
\hline 'No. of farmers & & &
\end{tabular}

Table 4. Watering practices at both sites in different seasons

\begin{tabular}{rcccccccc}
\hline Source $^{\#}$ & \multicolumn{2}{c}{ Spring } & \multicolumn{2}{c}{ Summer } & \multicolumn{2}{c}{ Rainy season } & \multicolumn{2}{c}{ Winter } \\
\cline { 2 - 8 } & Site-I & Site-II & Site-I & Site-II & Site-I & Site-II & Site-I & Site-II \\
\hline River & $26^{*}$ & 9 & $26^{*}$ & 9 & $26^{*}$ & 9 & $26^{*}$ & 10 \\
Well & 2 & 3 & 2 & 1 & 2 & 2 & 2 & 2 \\
Pond & $52^{* *}$ & 3 & $52^{* *}$ & 5 & $52^{* *}$ & 4 & $52^{* *}$ & 3 \\
Pipe water & 2 & 0 & 2 & 0 & 2 & 0 & 2 & 0 \\
Hand & 7 & $96^{* *}$ & 7 & $96^{* *}$ & 7 & $96^{* *}$ & 7 & $95^{* *}$ \\
pump & & & & & & & & \\
Others & $34^{*}$ & 12 & $34^{*}$ & 12 & $34^{*}$ & 12 & $34^{*}$ & 12 \\
\hline$*=\mathrm{P}<0.05 ; * *=\mathrm{P}<0.01 ;{ }^{*}$ No. of farmers & & & & & &
\end{tabular}

Table 5. Watering frequency at two sites

\begin{tabular}{lccc}
\hline Watering frequency & ${ }^{\#}$ Site-I & ${ }^{\#}$ Site-II & Significance level \\
\hline Once a day & 4 & 27 & 0.004 \\
Twice a day & 87 & 71 & 0.048 \\
Thrice a day & 28 & 17 & 0.001 \\
Through the day & 0 & 2 & 0.509 \\
Others & 1 & 5 & 0.643 \\
\hline
\end{tabular}

${ }^{\#}$ No. of farmers who responded to questionnaire

Table 6. Who collects water for goats

\begin{tabular}{lccc}
\hline Who collects water & Farmers at Site-I & Farmers at Site-II & Significance Level \\
\hline Household $(\mathrm{HH})$ head & 26 & 9 & 0.001 \\
Spouse & 35 & 34 & 0.901 \\
All HH & 19 & 20 & 0.564 \\
Head's father & 1 & 0 & 0.800 \\
Head's mother & 1 & 0 & 0.800 \\
Son/daughter & 19 & 23 & 0.520 \\
Hired labour & 2 & 1 & 0.553 \\
All or any HH member & 11 & 8 & 0.049 \\
Others & 2 & 2 & 0.850 \\
\hline
\end{tabular}


Table 7. Feeding and watering management of goats at two experimental sites

\begin{tabular}{lcccccc}
\hline Household member & \multicolumn{2}{c}{ Who waters } & \multicolumn{2}{c}{ Who prepares } & \multicolumn{2}{c}{ Who feeds goats } \\
\cline { 2 - 7 } & Site-I & Site-II & Site-I & Site-II & Site-I & Site-II \\
\hline Men & 53 & 49 & 64 & 59 & 60 & 60 \\
Women & $42^{*}$ & 28 & $26^{*}$ & 19 & 31 & 27 \\
Children & 2 & $8^{*}$ & 1 & $8^{*}$ & 1 & $7 *$ \\
All or any adult & $17^{*}$ & 7 & $14^{*}$ & 6 & $15^{*}$ & 6 \\
All or any HH member & 7 & $14^{*}$ & 6 & $13^{*}$ & 6 & $13^{*}$ \\
\hline$*=\mathrm{P}<0.05{ }^{\$}$ No of farmers & & & & & &
\end{tabular}

\section{CONCLUSION}

It was apparent that rural people offered cheaper and easily available feed stuffs to goats. The gender involvement showed active participation of both sexes. Availability of pure and fresh water was not cheaper and drew sufficient expenses in keeping goats. Sites differed for various feeding and watering practices. Farmers training to better utilize available resources and improvement of pasture lands and other necessities would enhance goat productivity and lead towards efficient utilization of available genetic resources. It is foreseen that increase in flock size, development of grazing lands and pastures and enough watering facilities would improve goat production in the rural Punjab in Pakistan, and would lead towards poverty alleviation.

\section{ACKNOWLEDGEMENT}

Work was partially sponsored by GEF-UNEP-ILRI FAnGR Asia Project "Development and Application of Decision Support Tools to Conserve and Sustainably Use Genetic Diversity in Indigenous Livestock \& Wild Relatives".

\section{REFERENCES}

Ayalew, W., Rischkowsky, B., King, J.M. and Bruns, E. (2003). Crossbreds did not generate more net benefits than indigenous goats in Ethiopian smallholdings. Agricultural Systems 76, $1137-1156$.

Ellis, F. (2003). Peasant economics: Farm households and agrarian development. Cambridge University Press, Cambridge, NY, USA. Pp. 171.

Finan, A. (2011). For the love of goats: the advantages of alterity. Agriculture and Human Values 28, 81 - 96.

Panin, A. (2000). A comparative economic analysis of smallholder cattle and small ruminant production systems in Botswana. Tropical Animal Health and Production 32, 189 - 196.

SPSS Inc. Released (1999). IBM SPSS Statistics for Windows, Version 10.0: IBM Corp. Armonk, NY, USA. 